\title{
SIPENSA: Sistem Informasi Penerimaan Siswa Baru Di SMK Astrindo
}

\author{
Suleman ${ }^{1}$, Pudji Widodo ${ }^{2}$, Bambang Kelana Simpony ${ }^{3}$, Ella Restiya Melati ${ }^{4}$ \\ Universitas Bina Sarana Informatika ${ }^{1234}$ \\ suleman.sı@@bsi.ac.id¹, pudji.piw@bsi.ac.id² ${ }^{2}$, bambang.bky@bsi.ac.id ${ }^{3}$, ellarestiyamelati@gmail.com ${ }^{4}$
}

\begin{abstract}
Abstrak - Penerimaan Siswa Baru (PSB) adalah salah satu kegiatan yang memiliki peran penting dalam suatu lembaga pendidikan dalam proses penyelenggaraan pendidikan yang baik, khususnya dalam proses pendaftaran siswa baru sampai dengan pengumuman siswa baru yang diterima. Proses penerimaan siswa baru yang dilakukan oleh SMK Astrindo saat ini masih dilakukan secara manual, sehingga kadang ditemukan masalah seperti: penginputan data yang lambat, berkas pendaftaran yang kadang hilang, dan antrian pendaftaran yang panjang. Untuk dapat mengatasi permasalahan yang terjadi dalam proses PSB ini, dan dalam membantu pencarian sekolah sesuai yang dibutuhkan dengan keingian masyarakat, maka perlu dibuatkan suatu sistem pendukung tentang penerimaan siswa baru, maka dirasa perlu dibuatkan Sistem Informasi Penerimaan Siswa Baru (PSB) di SMK Astrindo berbasis web yang di bangun menggunakan framework codeigniter dengan konsep Model-View-Controller (MVC), Tujuan dari sistem PSB ini, mempermudah bagi calon siswa yang akan mendaftar di SMK Astrindo Kota Tegal karena dapat dilakukan secara online. Sehingga memudahkan pihak sekolah dan efisien dalam mengelola data calon siswa. Dalam pembuatan sistem PSB ini dikembangkan menggunakan script PHP, MYSQL dan CSS. Desain dibangun menggunakan Atom.
\end{abstract}

Kata Kunci : Sistem Informasi, Penerimaan Siswa Baru, SMK Astrindo

\begin{abstract}
New Student Admission (PSB) is an activity that has an important role in an educational institution in the process of providing good education, especially in the process of registering new students to the announcement of new students being accepted. The process of accepting new students carried out by SMK Astrindo is currently still done manually, so that sometimes problems are found such as: slow data entry, sometimes missing registration files, and long registration queues. To be able to overcome the problems that occur in the PSB process, and in helping to find schools that suit the needs and desires of the community, it is necessary to create a support system for new student admissions, it is deemed necessary to create a New Student Admissions Information System (PSB) at SMK Astrindo web-based which was built using a codeigniter framework with the concept of Model-view-controller (MVC). The purpose of this PSB system is to make it easier for prospective students who will register at SMK Astrindo Tegal City because it can be done online. So that the school will be easier and more efficient in managing the data of prospective students. In making the PSB system, it was developed using PHP, MYSQL and CSS scripts. The design is built using Atom Keywords: Information Systems, Acceptance of New Students, SMK Astrindo
\end{abstract}

\section{PENDAHULUAN}

Perkembangan teknologi setiap waktunya semakin pesat, banyak inovasi diantaranya pada perangkat canggih yang bisa dibawa kemana saja hanya dengan genggaman tangan. Dengan perkembangan teknologi tentu saja kegiatan di perusahaan, sekolah, universitas dan instansi lainnya menjadi relatif mudah dan efisien (Sidik \& Rahmawati, 2018).

Pada proses pendaftaran siswa baru, karena sudah ada yang namanya perkembangan teknologi seharusnya sudah bisa dilakukan dimana saja dan kapan saja. Misalnya dirumah, diluar kota serta tidak perlu datang ke sekolah untuk mengantri mengambil formulir pendaftaran serta dalam proses pembayaran juga bisa dilakukan secara online.

Proses pendaftaran siswa baru yang mulanya menggunakan sistem manual memiliki kelemahan. Sistem seperti ini sering kali menyebabkan terjadinya kesalahan data, sehingga membuat sistem tidak efektif dan efisien dalam proses pendaftaran siswa baru (Sunarti, 2015).

Salah satu yang masih menggunakan sistem manual yaitu SMK Astrindo Kota Tegal, selama ini informasi yang berhubungan pada SMK Astrindo Kota Tegal masih disampaikan dalam bentuk informasi seperti menyebarkan brosur, memasang spanduk atau promosi ke calon siswa yang berada disekitar lingkungan sekolah. Begitupun proses pendaftaran siswa baru masih dilakukan dengan sistem manual.

SMK Astrindo Kota Tegal memiliki empat jurusan yaitu: Akuntansi, Teknik Kendaraan Ringan, Teknik Komputer Jaringan, dan Multimedia.

Penerapan sistem pendaftaran manual pada penerimaan peserta didik baru dan semakin bertambahnya calon siswa yang mendaftar setiap tahunnya, harus mengikuti prosedur yaitu mengisi formulir, pengembalian formulir, pembagian nomor induk dan pembagian kelas. Selain kurang efisien bagi para calon siswa, 
sistem manual juga berdampak pada bagian administrasi, karena harus mencatat data yang cukup banyak.

Untuk mempermudah dalam sistem pendaftaran tersebut maka perlu adanya sebuah Sistem Informasi Pendaftaran Siswa Baru (PSB) pada SMK Astrindo Kota Tegal.

Menurut (Rahayu \& Suandi, 2017) perancangan sistem informasi penerimaan siswa baru berbasis website di sekolah, bisa membantu mempermudah pendaftaran sehingga calon siswa tidak perlu datang langsung ke sekolah. Dengan adanya sistem komputerisasi mempermudah pelayanan sehingga mengurangi antrian pendaftar. Sistem ini juga dapat mencetak siswa yang mendaftar juga siswa yang diterima, sehingga laporan data siswa yang diterima akan tersusun lebih rapi dan akurat.

Menurut (Marisa, 2017) Website merupakan kumpulan halaman yang digunakan untuk mempublikasikan informasi berbentuk teks, foto atau gambar serta program multimedia lainnya berbentuk animasi, suara serta gabungan dari seluruhnya baik yang statis maupun dinamis yang terhubung antara halaman satu dengan halaman lainnya yang kerap disebut hyperlink. Website dibanguan dengan bahasa PHP yaitu suatu bahasa pemrograman yang digunakan untuk menterjemahkan baris kode program menjadi kode mesin yang dapat dimengerti oleh komputer dan bersifat server-side serta dapat di tambahkan kedalam HTML (Supono \& Putratama, 2016). Serta menggunakan framework Code Igniter. Untuk mendukung sistem informasi berbasis web tentunya harus ada pengelolaan database. Pada penelitian ini menggunakan database MYSQL.

Adanya website ini, diharapkan segala informasi yang berhubungan dengan SMK Astrindo Kota Tegal, seperti profil sekolah, berita sekolah, kejuruan, ekstrakurikuler, serta menu PSB dapat menyebarluas baik untuk masyarakat umum maupun bagi siswa, guru, dan karyawan SMK Astrindo Kota Tegal pada khususnya. Selain itu dengan adanya penerimaan siswa baru secara online ini lebih mempermudah masyarakat untuk mendaftar di SMK Astrindo Kota Tegal yang selama ini masih mendaftar secara manual.

\section{METODOLOGI PENELITIAN}

Metode penelitian yang penyusun gunakan adalah sebagai berikut:

A. Metode Pengembangan perangkat lunak Metode pengembangan perangkat lunak ini menggunakan model waterfall (A.S \& Shalahuddin, 2014) terdiri dari lima tahapan, yaitu:

1. Analisis kebutuhan Perangkat Lunak

Pada tahap ini penyusun melakukan pengumpulan kebutuhan perangkat lunak yang mana dalam sistem ini terdapat tiga hak akses yaitu hak akses admin user dan pengguna serta terdapat beberapa menu seperti menu home, profil sekolah, berita sekolah, kejuruan, ekstrakurikuler, serta menu PSB bagi siswa yang akan mendaftar melalui online.

\section{Desain}

Tahap desain merupakan tahap perancangan program seperti struktur navigasi, diagram alur, basis data, dan tabel yang dibutuhkan, digambarkan dalam bentuk Entity Relationship Diagram (ERD).

3. Pengkodean

Tahap pengkodean adalah pembuatan kode program yang merupakan penerapan hasil dari tahap desain yang telah dibuat kedalam bahasa pemrograman seperi HTML. PHP, CSS dan Javascript dengan bantuan software Atom serta XAMPP sebagai web server.

4. Pengujian

Tahap pengujian yang digunakan yaitu black box testing yaitu merupakan pengujian secara fungsional seperti pengujian untuk validasi yang meliputi pengujian login, pengujian admin, dan user.

5. Pemeliharaan

Kemungkinan sebuah perangkat lunak mengalami perubahan ketika sudah dikirim ke user sehingga perubahan bisa terjadi karena adanya kesalahan yang muncul.

\section{B. Teknik Pengumpulan Data}

Pengumpul data dilakukan menggunakan beberapa teknik, diantaranya:

1. Pengamatan (Observation)

Penyusun melakukan pengamatan langsung terhadap objek yang akan dipakai untuk penelitian dan mengamati sistem yang berhubungan dengan sistem informasi pendaftaran SMK Astrindo Kota Tegal.

Hasil dari pengamatan yang berupa sistem yang dibutuhkan sekolah yang kemudian langsung di catat oleh penyusun dan dari kegiatan observasi itu diketahui bagaimana sistem pendaftaran yang sedang berjalan saat ini.

\section{Wawancara (Interview)}

Untuk mendapatkan informasi secara lengkap, penyusun melakukan suatu metode tanya jawab dengan guru yang bertugas di penerimaan siswa baru untuk mengetahui permasalahan yang ada pada sistem informasi sekolah serta untuk mendapatkan data yang berhubungan dengan pendaftaran siswa baru 
pada SMK Astrindo Kota Tegal.

3. Studi Pustaka

Penyusun melakukan kegiatan studi kepustakaan yaitu untuk mendapatkan referensi melalui ebook, buku, jurnal, dan referensi lain yang mendukung.

\section{HASIL DAN PEMBAHASAN}

Sesuai dengan tahapan pada metode peneltian yang sudah dijelaskan diawal, maka perancangan dan implementasi memiliki beberapa tahapan, yaitu:

1. Analisis kebutuhan apa saja yang nanti akan diterapkan di perangkat lunak, terdiri dari 2 kebutuhan yaitu:

a. Kebutuhan Pengguna

Terdapat tiga pengguna yang saling berinteraksi dalam sistem pada website Sistem Informasi Penerimaan Siswa Baru Di SMK Astrindo Kota Tegal ini, yaitu admin, user dan pengunjung. Ketiga pengguna memiliki kekhususan dalam interaksi dan kebutuhan sistem yang berbeda-beda. Admin mengelola manajemen user yang berhubungan dengan data: profil sekolah, berita/informasi, galeri, data kategori, pendaftar, dan pengumuman.

User bisa melakukan pendaftaran online melalui website, melakukan login memasukan username dan password yang telah terdaftar, mengelola data pribadi pada halaman menu, edit akun, dan logout.

Pengunjung hanya memiliki akses melihat menu home, profil sekolah, kategori berita sekolah, galeri, dan menu PPDB serta kontak kami. Dapat melakukan pendaftaran pada halaman menu PPDB untuk kebutuhan mendaftar dan login user.

b. Kebutuhan Sistem

Dalam hal ini sistem menyediakan menu beranda, tentang, kontak, cari perlengkapan, artikel dan pengaduan. Sistem juga menyediakan form registrasi untuk pengunjung web, sehingga terdaftar sebagai user dan dapat melakukan pengaduan.

Selain itu, sistem menyediakan informasi mengenai titik perlengkapan jalan yang ada di Kabupaten Tegal. Form pengaduan bagi masyarakat yang ingin mengadukan mengenai perlengkapan jalan yang ada di Kabupaten Tegal, juga disediakan oleh sistem. Laporan perlengkapan jalan, laporan jumlah member, dan laporan jumlah pengaduan, sistem juga menyediakan. Sistem menyediakan informasi grafik perlengkapan jalan, grafik jumlah member, dan grafik jumlah pengaduan.

2. Selanjutnya tahap desain dengan menggambarkan rancangan database menggunakan tools yaitu Unified Modelling
Language (UML) suatu metode pemodelan secara visual untuk sarana perancangan sistem berorientasi objek atau definisi UML yaitu sebagai bahasa yang sudah menjadi standar pada visualisasi, perancangan, dan pendokumentasian sistem software. Selain itu dibuat juga rancangan ERD (Entity Relationship Diagram) dan LRS (Logical Record Structure).

Berikut pada gambar 1 merupakan gambaran hasil rancangan menggunakan tools yang sudah dijelaskan diatas, diwakili dengan pembuatan LRS.

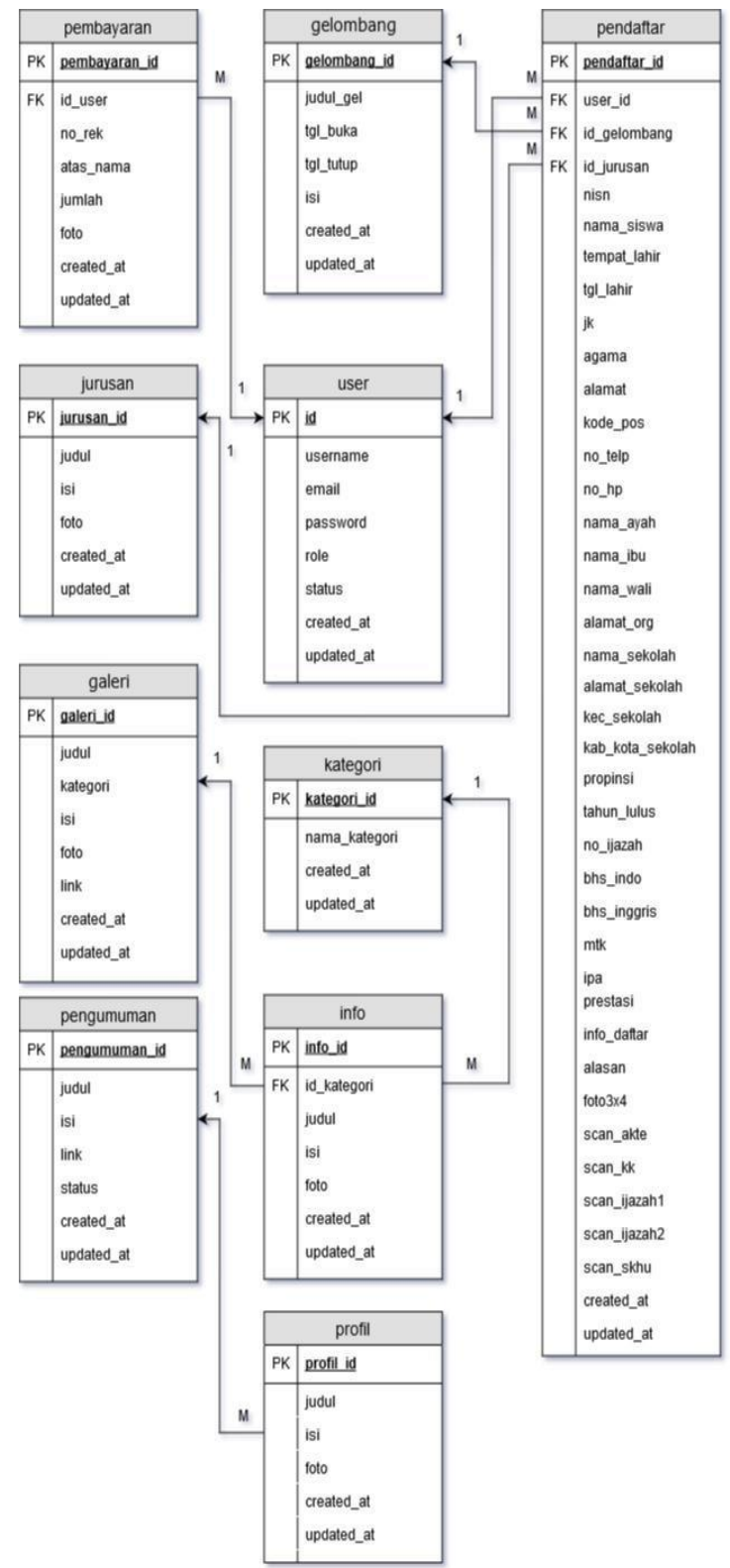

Sumber: Hasil Penelitian (2021)

Gambar 1. Rancangan Logical Record Structure SIPENSA

3. Tahap ini merupakn hasil dari pengkodean dan selanjutnya di implementasi dalam rancangan antar muka Sistem Informasi Penerimaan Siswa Baru pada SMK Astrindo Kota Tegal, yaitu: 
a. Tampilan Halaman Beranda

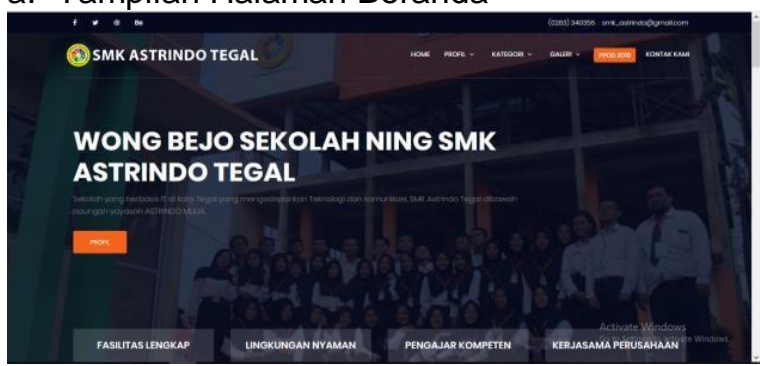

Sumber: Hasil Penelitian (2021)

Gambar 2. Implementasi Tampilan Halaman Beranda

Gambar 2 merupakan implementasi dari halaman beranda pengunjung dari web ini. Terdapat menu beranda, menu profil yang terdiri dari sejarah sekolah, visi \& misi, struktur organisasi. Menu lainnya yaitu kategori, galeri, menu PPDB, dan kontak kami.

b. Tampilan Form Login

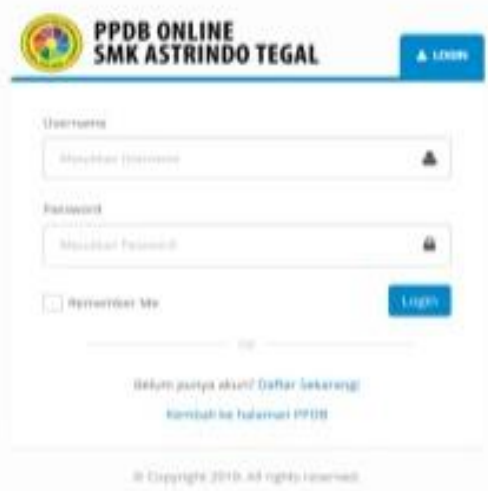

Sumber: Hasil Penelitian (2021)

Gambar 3. Implementasi Tampilan Form Login Gambar 3 merupakan implementasi dari Login yang merupakan form login bagi visitor yang sudah mendaftar.

c. Tampilan Halaman Form Daftar Sekarang

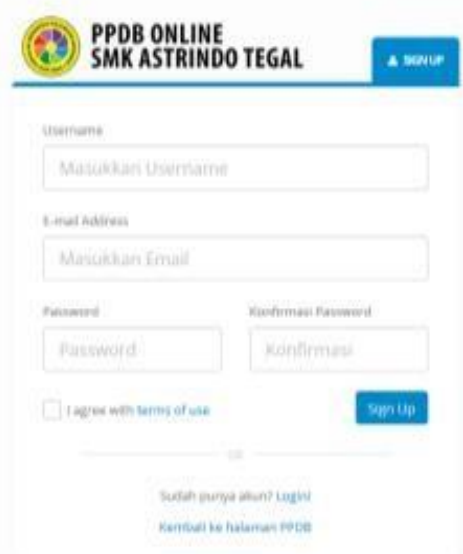

Sumber: Hasil Penelitian (2021)

Gambar 4. Implementasi Tampilan Form Daftar Sekarang
Gambar 4 merupakan implementasi dari halaman daftar sekarang yang terdapat di beranda PPDB untuk registrasi bagi calon siswa yang akan login ke halaman user.

d. Tampilan Halaman User

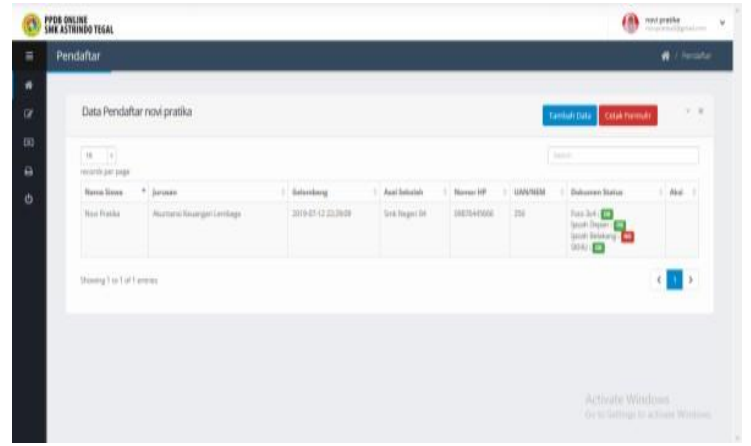

Sumber: Hasil Penelitian (2021)

Gambar 5. Implementasi Tampilan Halaman User

Gambar 5 merupakan implementasi dari halaman user yang terdapat menu beranda, pendaftaran, pembayaran, kartu Mos dan logout.

\section{e. Tampilan Halaman Form Pendaftaran}

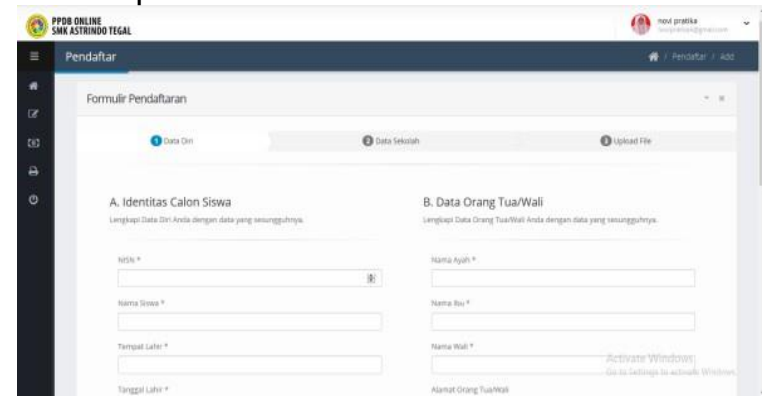

Sumber: Hasil Penelitian (2021)

Gambar 6. Implementasi Tampilan Halaman Form Pendaftaran

Gambar 6 merupakan implementasi dari halaman form pendaftaran yang berisi data diri, data sekolah, dan upload file.

\section{f. Tampilan Halaman Form Kartu MOS}

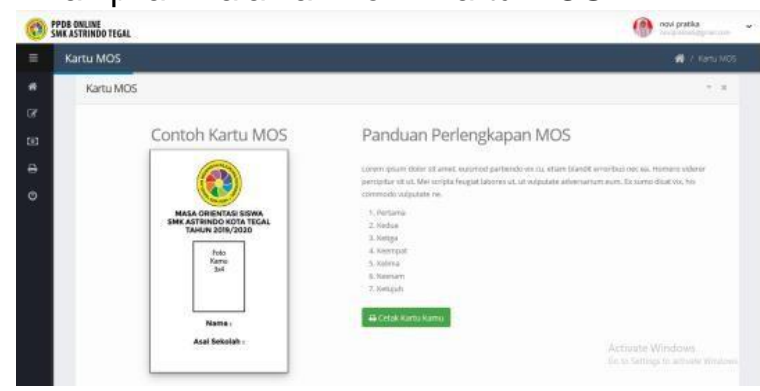

Sumber: Hasil Penelitian (2021)

Gambar 7. Implementasi Tampilan Cetak Kartu MOS (Masa Orientasi Siswa) 
Gambar 7 merupakan fitur yang menjadi inovasi di perancangan SIPENSA yaitu siswa bisa mencetak langsung Kartu MOS.

\section{g. Tampilan Halaman Beranda Admin}

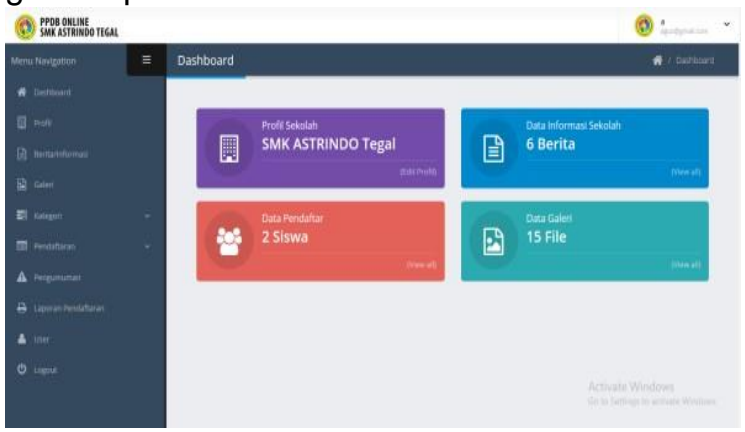

Sumber: Hasil Penelitian (2021)

Gambar 8. Implementasi Halaman Beranda Admin

Gambar 8 merupakan implementasi dari halaman beranda admin yang dapat dilihat setelah berhasil login admin. Terdapat gambar profil sekolah, data informasi sekolah, data daftar dan data galeri.

\section{KESIMPULAN}

Aplikasi Sistem Penerimaan Siswa Baru (PSB) dapat mempermudah informasi dan komunikasi. Dengan mengubah sistem yang sebelumnya masih manual menjadi sistem online berbasis website, mempermudah bagi calon siswa mendaftar pada SMK Astrindo Kota Tegal karena bisa melakukan pendafftaran dimana saja dan kapan saja. Manajemen data juga akan tersusun dengan baik dan mudah dalam pencarian data. Sehingga pihak sekolah lebih efisien dalam mengelola data calon siswa dan proses pendidikan menjadi lebih baik dan terarah. Selanjutnya sebagai saran dalam penelitian berikutnya yaitu terkait aturan zonasi dari pemerintah, maka bisa ditambahkan fitur zonasi di website untuk cek apakah tempat tinggal calon siswa sudah memenuhi syarat jarak maksimal.

\section{REFERENSI}

A.S, R., \& Shalahuddin, M. (2014). Rekayasa Perangkat Lunak Terstruktur dan Berorientasi Objek. Informatika.

Marisa, F. (2017). Web Programming untuk Membangun Portal. CV Budi Utama.

Rahayu, S., \& Suandi, W. (2017). Perancangan Sistem Informasi Penerimaan Siswa Baru Berbasis Web di Sekolah Menengah Atas Negeri 14 Garut. Algoritma, 14(2), 127134.

https://jurnal.itg.ac.id/index.php/algoritma/ article/view/505/478

Sidik, F., \& Rahmawati, M. (2018). Perancangan Sistem Informasi Pendaftaran Siswa Baru Berbasis Web Pada SMK Bina Putra Jakarta. Paradigma, $\quad X X(1), \quad$ 119-128. https://ejournal.bsi.ac.id/ejurnal/index.php/ paradigma/article/view/3051/pdf

Sunarti. (2015). Implementasi Sistem Informasi Penerimaan Siswa Baru Sunarti. Evolusi, 3(2), $\quad$ 1-4. https://ejournal.bsi.ac.id/ejurnal/index.php/ evolusi/article/view/608/499

Supono, \& Putratama, V. (2016). Pemrograman Web Dengan Menggunakan PHP dan Framework Codeigniter. Deepublish 